\title{
Big Cat Adaptation in the Mesoamerican Biodiversity Hotspot
}

Michael O'Neal Campbell*

Simon Fraser University, British Columbia, Canada

*Corresponding author: Michael O'Neal Campbell, Simon Fraser University, British Columbia, Canada, Tel: 2508163784; E-mail: ecol55@hotmail.com

Received date: July 20, 2015; Accepted date: July 22, 2015; Published date: July 30, 2015

Copyright: (C) 2015, Campbell MN. This is an open-access article distributed under the terms of the Creative Commons Attribution License, which permits unrestricted use, distribution, and reproduction in any medium, provided the original author and source are credited.

\section{Introduction}

The Mesoamerican Biodiversity Hotspot, part of the Neotropical ecological region, comprising Central America (Costa Rica, Belize, El Salvador, Nicaragua, Honduras, Guatemala and the northern half of Panama) and southern Mexico, is defined as a hotspot, because it is an area "featuring exceptional concentrations of endemic species and experiencing exceptional loss of habitat" [1]. Species and habitat loss has occurred as rainforest is converted to urban and farmed areas and mixed vegetation mosaics, due to urbanization, population increase, agricultural intensification, civil wars, deforestation, land use conflicts and inept conservation policy [2-14]. The new landscapes and increased human proximity favor small animals to the detriment of large carnivores such as the jaguar and cougar. Few studies have modeled the survival probability of large carnivores in this area, rooted in the behavioral characteristics of these animals across their wider ranges [15].

\section{Contrasts between the Jaguar and Cougar}

The jaguar (Panthera onca, Linnaeus 1758) and cougar (Puma concolor, Linnaeus 1771) are decisively the largest carnivorous mammals in the Mesoamerican region, distant competitors being the much smaller ocelot (Leopardus pardalis, Linnaeus 1758) and coyote (Canis latrans, Say 1823). Crucially, the comparatively large and possibly dangerous jaguars and cougars conflict with people in valued spaces, to the extent that both species are now extinct in El Salvador, one of the more environmentally degraded countries in Central America [16,17]. Jaguars are much less studied than lions, tigers and leopards, and those in South America are more popular than the Central American populations [18,19]. The more studied and widely ranging cougar is judged as less dangerous to people and more elusive than the larger jaguar [20].

Forest, with water proximity, gentle slopes and no human settlements is the favored habitat of both jaguars and cougars [21-27]. However, compared with the more versatile cougar, the jaguar is more restricted to tropical and sub-tropical forest at lower altitudes [28-31]. Jaguars are highly mobile, sensitive to human presence, have low population densities in large ranges (up to $1000 \mathrm{kms}^{2}$ ) and unpredictable behavioral patterns [32-34]. The cougar has a much wider range, and adapts more easily to shared land cover with larger carnivores and people, and reacts even more variably to human presence and modified land cover [35]. Jaguars and cougars avoid competition in shared land cover; the jaguar takes larger prey and the cougar favors smaller, more variable prey [36-39]. However, both species may kill livestock, either due to a scarcity of natural prey or individual behavior. This may lead to human action [40-42]. Consequently, allegedly problem cats have been hunted and killed [43-45]. However, assessments of the differences between jaguars and cougars, and intra-species behavior in adaptation to the degradation of
Mesoamerica is difficult, as the few behavioral studies in this and other regions have not contributed a utilitarian, comparative model of contrasting inter- and intra-species behavior.

\section{Animal Adaptation in Theory}

One possible model of big cat adaptation, that includes intra-species behavioral variation, may be derived from the flexible framework of animal geography, some strands of which model animals as subjects with active abilities (more similar to people) rather than as mechanistic, generalized objects in human life spaces. This format is better placed than classical ecology to record and explain adaptive carnivore behavior, especially as individual, "problem" cats are a critical issue [46-49]. This active ability or actancy refers to arguably human-like behavior, making free choices in response to different events [50]. Although risking criticism of anthropomorphization, this advantageously enables comparative investigation of the individualized adaptation strategies of animals (inter- and intraspecies) in degraded land cover and allows investigation of occurrences of individualized behavior [51]. These subjectivities may be neglected or undetected by the more positivist sciences of zoogeography and animal ecology; emphasis on these may also provide a stronger link with relevant human geographies of wildlife [52-59]. Embedded in this approach is a stronger theoretical uncovering of unique animal behavioral subjectivity connected to strands of cultural human geography, a hypothesis of shared actancy between people and animals and the juxtaposition of these with quantitative ecology [60,61].

\section{The Way Forward}

Currently, the big cats of the Mesoamerican Biodiversity Hotspot are among the more threatened members of their species. In other parts of the Americas, the jaguar is rare and declining, but the cougar is holding its own in some areas [62]. More knowledge of jaguar and cougar behavior across their respective ranges, based on a synthesis of individualized adaptation, inter-species generalization, habitat dynamics and human behavioral variations is plainly needed for ameliorative action. However, a common thread that links the disparate issues is needed. More studies must be added to the patchwork of big cat conservation and the likelihood of success is conditional on the breadth and flexibility of the approach. In this regard, an animal geography approach as described above offers a viable but untested integrative framework. Forward to the battle!

\section{References}

1. Myers N, Mittermeier RA, Mittermeier CG, da Fonseca GAB, Kent J (2000) Biodiversity hotspots for conservation priorities. Nature 403: 853-858. 
Page 2 of 3

2. Vandemeer J (1990) The Political Ecology of Sustainable Development The Southern Atlantic Coast of Nicaragua. CICLAES, Michigan State University.

3. Schelhas J (1996) Land use choice and change: intensification and diversification in the lowland tropics of Costa Rica. Human Organization 55: 298-304.

4. Simmons CS (1997) Forest management practices in the Bayano region of Panama: Cultural variations. World Development 25: 989-1000.

5. Howard SM (1998) Land conflict and Mayangna territorial rights in Nicaragua's Bosawás reserve. Bulletin of Latin American Research 17: 17-34.

6. Nassar-Montoya F, Crane R (eds) (2000) Attitudes Toward Wildlife in Latin America. Humane Society Press, Washington DC.

7. Ramos LA, Ricord de Mendoza Z (2000) Tenencia de fauna Silvestre en El Salvador. In: Nassar-Montoya F. and Crane, R. (eds) Actitudes hacia la fauna en Latinoamérica, Humane Society Press, Washington DC, 85-95pp.

8. Sanchez-Azofeifa, GA (2000) Land use and cover change in Costa Rica. In: Hall C. (eds), Quantifying Sustainable Development, Academic Press, New York, pp2. 477-505.

9. Vargas-Mena E (2000) Significados culturales de la tortuga verde (Chelonia mydas) en el Caribe costarricense. In: Nassar-Montoya F. and Crane R. Actitudes hacia la fauna en Latinoamérica, Humane Society Press, Washington DC, 161-176.

10. Southworth J, Tucker C (2001) The influence of accessibility local institutions and socio- conomic factors on forest cover change in the mountains of Western Honduras. Mountain Research and Development 21: $276-283$.

11. Drews C (2002) Attitudes, knowledge and wild animals as pets in Costa Rica. Anthrozoös 15(2): 119-138.

12. Hecht SB, Kandel S, Gomes I, Cuellar N, Rosa H (2006) Globalization forest resurgence, and environmental politics in El Salvador. World Development 34: 308-23.

13. Sloan S (2007) Fewer people may not mean more forest for Latin American forest frontiers. Biotropica 39: 443-446.

14. Taylor MJ (2007) Militarism and the environment in Guatemala. GeoJournal 69(3): 181-198.

15. Campbell $M$ and Torres Alvarado $M$ (2011) Public perceptions of jaguars Panthera onca pumas Puma concolor and coyotes Canis latrans in El Salvador. Area 433: 250-256.

16. Michalski F, Boulhosa RLP, Faria A, Peres CA (2006) Human-wildlife conflicts in a fragmented Amazonian forest landscape: determinants of large felid depredation on livestock. Animal Conservation 9: 79-88.

17. Palmeira F, Crawshaw P, Haddad C, Ferraz K, Verdade L (2008) Cattle Depredation by Puma (Puma concolor) and Jaguar (Panthera onca) in Central-Western Brazil. Biological Conservation 141: 118-125.

18. Brodie JF (2009) Is research effort allocated efficiently for conservation? Felidae as a global case study. Biodiversity Conservation 18: 2927-2939.

19. Cavalcanti S, Gese EM (2010) Kill rates and predation patterns of jaguars (Panthera onca) in the southern Pantanal, Brazil. Journal of Mammalogy 91: 722-736.

20. Conforti VL and Azevedo FCC (2003) Local perceptions of jaguars Panthera onca and pumas Puma concolor in the Iguacu National Park area south Brazil. Biological Conservation 111: 215-221.

21. Farrell LE, Roman J, Sunquist ME (2000) Dietary separation of sympatric carnivores identified by molecular analysis of scats. Molecular Ecology 9: 1583-1590.

22. Núñez R, Miller B, Lindzey F (2002) Ecología del jaguar en la reserva de la biosfera Chamela-Cuixmala, Jalisco, México. In: Medellín R, Equhua C, Chetkiewics C, Crawshaw P, Robinowitz et al. (eds.) El Jaguar en el Nuevo Milenio, Fondo de Cultura Económica-Wildlife Conservation SocietyUNAM, México, 107-126pp.

23. Scognamillo D, Maxit IE, Sunquist M, Polisar J (2003) Coexistence of jaguar (Panthera onca) and puma (Puma concolor) in a mosaic landscape in the Venezuelan Ilanos. Journal of Zoology, London 259: 269-279.
24. Wallace RB, Gomez H, Ayala G, Espinoza F (2003) Camera trapping capture frequencies for jaguar (Panthera onca) in the Tuichi Valley, Bolivia. Mastozoologia Neotropical 10: 133-139.

25. Monroy-Vilchis O, Sanchez O, Acuilera-Reyes U, Suarez P, Urios V (2008) Jaguar (Panthera onca) in the state of Mexico. Southwestern Naturalist, 53: 533-537.

26. Monroy-Vilchis O, Gómez Y, Janczur M, Urios V (2009) Food niche of Puma concolor in Central Mexico. Wildlife Biology 15: 1- 9.

27. Monroy-Vilchis O, Rodríguez-Soto C, Zarco-González M, Urios, V (2009) Cougar and jaguar habitat use and activity patterns in central Mexico. Animal Biology 59: 145-157.

28. Sunquist M, Sunquist F (2002) Wild Cats of the World. The University of Chicago Press, Chicago.

29. Lopez-Gonzalez CA, Brown DE (2002) Distribution and state of conservation of the jaguar northwestern Mexico. In: Medellin RA, Equihua C, Chetkiewicz CLB, Crawshaw PG, Rabinowitz A et al. (eds) The Jaguar in the New Millennium, Mexico University Scientific Editions, pp2 379-392.

30. Hatten JR, Averill-Murray A, van Pelt WE (2005) A spatial model of potential jaguar habitat in Arizona. Journal of Wildlife Management 69(3): 1024-33.

31. Navarro-Serment CJ, Lopez-Gonzalez CA, Gallo-Reynoso JP (2005) Occurrence of Jaguar (Panthera onca) in Sinaloa, Mexico. The Southwestern Naturalist 50: 102-106.

32. Silver SC, Ostro LET, Marsh LK, Maffei L, Noss AJ et al. (2004) The use of camera traps for estimating jaguar Panthera onca abundance and density using capture-recapture analysis. Oryx 38: 148 - 154.

33. Cullen L Jr (2006) Jaguar as landscape detectives for the conservation in the Atlantic Forest of Brazil. Ph.D. thesis, University of Kent, Canterbury.

34. Paviolo A, De Angelo CD, Di BlancoYE, Di Bitetti MS (2008) Jaguar Panthera onca population decline in the Upper Paraná Atlantic Forest of Argentina and Brazil. Oryx 42: 554-561.

35. López-González CA, González A (1998) A synthesis of current literature and knowledge about the ecology of the puma (Puma concolor). Acta Zoologica Mexicana 75:171-190.

36. Jaksic FM, Greene HW, Yáñez JL (1981) The guild structure of a community of predatory vertebrates in central Chile. Oecologia 49: 21-28.

37. Rabinowitz A, Nottingham B (1986) Ecology and behavior of the jaguar in Belize, Central America. Journal of Zoology 210: 149-159.

38. Iriarte JA, Franklin WL, Johnson WE, Redford KH (1990) Biogeographic variation of food habits and body size of the American Puma. Oecologia 85: $185-190$

39. Emmons LH (1991) Body size and feeding tactics. In: Seidensticker J, Lumpkin S (eds) Great Cats, Rodale Press, Emmaus, 62pp.

40. Schaller GB, Crawshaw PG (1980) Movement patterns of jaguar. Biotropica 12: 161-168.

41. Yáñez JL, Cárdenas JC, Gezelle P, Jaksic FM (1986) Food habits of the southernmost mountain lions (Felis concolor) in South America: natural versus livestocked ranges. Journal of Mammalogy 67: 604-606.

42. Nowell K, Jackson P (1996) Wild cats: Status survey and conservation action plan. IUCN/SSC Cat Specialist Group, Gland.

43. Swank WG, Teer JG (1989) Status of the jaguar. Oryx 23: 14 - 21.

44. Emmons LH (1990) Neotropical Rainforest Mammals: A Field Guide. University of Chicago Press, Chicago.

45. Sanderson EW, Redford RH, Chetkiewicz CB, Medellin R, Rabinowitz A et al. (2002) Planning to save a species: the jaguar as a model. Conservation Biology 16: 58-72.

46. Wolch J, Eme, J (eds) (1998) Animal Geographies: Place, Politics, and Identity in the Nature Culture Borderlands Verso, London.

47. Lorimer J (2007) Nonhuman charisma. Environment and Planning D: Society and Space 25: 911-932.

48. Campbell M (2009) A new zoogeography of domestication and agricultural planning in Southern Ghana. Area 41(2): 139-148.

49. Barua M (2013) Volatile ecologies: towards a material politics of humananimal relations. Environment and Planning A: doi: 10.1068/a46138. 
Citation: Campbell MN (2015) Big Cat Adaptation in the Mesoamerican Biodiversity Hotspot. J Biodivers Endanger Species 3: e126. doi:

Page 3 of 3

50. Campbell M, Torres Alvarado M (2011) Public perceptions of jaguars Panthera onca, pumas Puma concolor and coyotes Canis latrans in El Salvador. Area 433: 250-256.

51. Murdoch J (1998) The spaces of actor network theory. Geoforum 29: 35774.

52. MacDonald G (2003) Biogeography: Introduction to Space, Time, and Life. John Wiley \& Sons, New York.

53. Campbell M (2015) The adaptation of the Turkey Vulture (Cathartes aura, Linnaeus 1758) to changing circumstances and ecologies. In: Jenkins OP (eds) Advances in Zoology 7. Nova Publishers, New York.

54. Sauer CO (1952) Agricultural Origins and Dispersals. American Geographical Society, New York.

55. Bennett CF (1960) Cultural animal geography: an inviting field of research Professional Geographer 12: 12-14.

56. Anderson K (1997) A walk on the wild side: a critical geography of domestication. Progress in Human Geography 21: 463 - 485.

57. Philo C, Wilbert C (2000) Animal Spaces, Beastly Spaces: New Geographies of Human-Animal Relations. Routledge, London.
58. Yarwood R, Evans N (2000) Taking stock of farm animals and rurality. In: Philo C, Wilbert C (eds.) Animal Spaces, Beastly Spaces: New Geographies of Human-Animal Relations, Routledge, London 98-114pp.

59. Emel J, Wilbert C, Wolch J (2002) Society and animals. Journal of Human Animal Studies 10: 1.

60. Johnston RJ, Gregory D, Pratt G, Watts M (2000) Human Geography. Blackwell, Malden.

61. Emel J, Urbanik J (2010) Animal geographies: exploring the spaces and places of human-animal encounters. In: DeMello M. (Eds) Teaching the Animal: Human-Animal Studies across the Disciplines, Lantern Books, New York 200-217.

62. Campbell M (2012) The relevance of age and gender for public attitudes to brown bears (Ursus arctos) black bears (Ursus americanus) and cougars (Puma concolor) in Kamloops British Columbia. Society and Animals 21: 341-359. 